\title{
Foundation Year Students' Perceptions of Using Social Network Sites for Learning English in the Saudi Context
}

\author{
Rana Al-Shoaibi ${ }^{1} \&$ Nadia Shukri ${ }^{2}$ \\ ${ }^{1}$ The English Language Institute, King Abdulaziz University, Jeddah, Saudi Arabia \\ ${ }^{2}$ The English Language Institute, King Abdulaziz University, Jeddah, Saudi Arabia \\ Correspondence: Nadia Shukri, English Language Institute, King Abdulaziz University, Jeddah, Saudi Arabia. \\ Tel: 056-688-0607. Emal: nashukri@kau.edu.sa
}

Received: March 1, 2017 Accepted: May 20, 2017 Online Published: May 26, 2017

doi: 10.5539/elt.v10n6p60 URL: http://doi.org/10.5539/elt.v10n6p60

\begin{abstract}
The major aim of this study is to better understand the university students' perceptions and attitudes towards using social network sites for learning English as well as to identify if there is a difference between male and female university students in terms of using social networking sites for learning English inside and outside the classroom. The study also attempts to identify the social networking sites that are most frequently used by male and female university students in order to learn English. The participants of this study were 20 female and male foundation year students at King Abdul Aziz University in Jeddah, Saudi Arabia. The tool of the study was a questionnaire. The finding of this study showed that male students had positive perceptions and attitudes toward using social network sites for learning English more than female students who had negative perceptions and attitudes. The results also showed that YouTube website was the most frequently used social network site for learning English by male students while the majority of the female students did not have any favorite social network sites because they did not use social network sites for learning English.
\end{abstract}

Keywords: gender difference, learning English, social network sites, Saudi Arabia

\section{Introduction}

At the present time, social network sites such as YouTube, Twitter, and Facebook have gained huge popularity around the world and for that, they have received many attention from people around the world (Silius et al., 2010). As a matter of fact, social networking sites in recent years, and especially in the fields of communication and knowledge sharing and information, have caused a huge transformation (Espuny, Gonzalez, Lleixà, \& Gisbert, 2011).

Social networking sites have been able to attract the attention of the younger generation in particular who were born in the digital age. Additionally, they have been able to attract the attention of students' universities (Brady, Holcomb, \& Smith, 2010). Due to social network sites, interactive features and their multidimensional characteristics, they provide users with the chance to express and share their opinions, ideas, and beliefs freely and quickly with other people around the world. According to a study by Harrison and Thomas (2009), social networking sites can directly impact learning, especially the learning of the English language because of the language's interactive nature. Several other studies support this study's claim (Godwin-Jones, 2006; Lomick \& Lord, 2003) which also emphasizes the potential of social networking sites for learning and teaching English language as well as for improving learners' language skills such as written and oral skills.

Social networking sites can influence students' self-confidence and motivation to learn English. Thus, students' perceptions, preferences and attitudes towards the idea of using social networking sites for learning English is a noteworthy factor to study. It is indeed very essential to understand and determine students' perceptions and attitudes toward the use of social networking sites for learning English. According to Azjen and Fishbein (1980), attitudes and perceptions are influenced by beliefs, which are the basis of behaviors. Therefore, we can say that if students have a positive or negative view, this view in turn affects the students' intention and willingness of performing in an activity or not. Attitudes and perceptions also affect students' quality and amount of participation. Furthermore, Glover and Brunin (1990) state that the attitude people have toward any issue in life, whether negatively or positively, will affect people's level of acceptance, intention, and the nature of their 
interaction. It is essential to be aware of students' perceptions and attitudes towards social networking sites because both students' and teachers' behavior can be anticipated based on the foundation of their acceptance or not, of using social networking sites. For this reason, understanding and identifying students' perceptions and attitudes toward using social networking sites for learning English can be used as a way to help adopt usage of these social networking sites in a more practical and constructive way either inside or outside classrooms to enhance students' language skills. Moreover, it is essential to determine gender differences in terms of using social networking sites for learning English especially regarding the gender differences attitude and perception of the idea of using social networking sites for learning English inside and outside of the classroom.

\subsection{Background}

Social networking sites have transformed the way individuals and societies socialize and communicate with one another, social networking sites also have transformed the method of how people share information, exchange knowledge, and learn. Several educators in the field realize that social networking sites are powerful tools that can transform learning, as students can use social networking sites for learning purposes either inside or outside of the classroom. According to Seo (2013), social networking sites provide students with the chance to build and share knowledge with global audience beyond the walls of classrooms. They also help students improve their skills and to develop their independence. They give learners the chance to become involved in adjustable and lifelong learning, and link and communicate with other people around the world. Moreover, they students become open minded, self-directed students. Therefore, it is important to examine students' attitudes towards using social networking sites for learning English, to investigate whether or not there are any gender differences when using those sites for learning English, and what social networking sites are used frequently by male and female students. This exploration can assist teachers to understand how students learning experiences and practices are connected to social networking sites, which in turn will help them get a better comprehension of how to integrate them for learning purposes.

\subsection{Statement of the Problem}

The main purpose of the study is to understand students' perceptions and attitudes towards using social networking sites for learning English as well as to identify if there is a difference between males and females in terms of using them for learning English inside and outside the classroom. The study also attempts to identify the social networking sites that are frequently used by female and male students in order to learn English.

\subsection{Objectives of the Study}

1) To understand the students' perceptions and attitudes towards using social networking sites for learning English.

2) To determine if there is a difference between male and female foundation year students in terms of learning English through social networking sites inside and outside of the classroom.

3) To identify the frequently used social networking sites that are used by male and female students to learn English.

\subsection{Research Questions}

1) What are the students' perceptions and attitudes towards using social networking sites for learning English?

2) Is there a difference between male and female foundation year students in terms of learning English through social networking sites inside and outside of the classroom?

3) What are the social networking sites that are frequently used by female and male foundation year students in order to learn English?

\section{Literature Review:}

\subsection{What are Social Networking Sites}

Social networking sites have transformed the way that people create knowledge, learn, get information, and how to take part in different styles of learning practices.

Social networking sites can be defined as "web-based sites that provide services which enable people to do three things: "(a) construct a public or semi-public profile within a bounded system, (b) articulate a list of other users with whom they share a connection, and (c) view and traverse their list of connections and those made by others within the system" (Boyd \& Ellison, 2007, p. 211). Therefore, social networking sites are Web-based sites that give users the opportunity to create one or more profiles in order to make connections with people around the world (Boyd \& Ellison, 2007). 


\subsection{Social Network Sites and Learning}

The use of the Internet and social networking sites for learning English can improve the learning process because these sites provide learners with the chance to share and obtain knowledge, collaborate, and communicate without the need for any skills related to special computer knowledge. Social networking sites encourage and support the notion of an open-ended learning environment. Moreover, they give learners the possibilities to be exposed to various activities that give them the chance to improve their language skills whether in writing, listening, speaking, and reading.

Nowadays, every aspect of society is affected by the Internet and technology. Social networking sites such as YouTube, Twitter, and Facebook provide people with a way to exchange unlimited information. They have not only affected the method that people use to communicate and conduct their day to day business, they also present a new method within the context of learning and teaching. They are easy to use by students, so even users with modest technology knowledge can use these sites for learning. Through their use, the learning activity can become a life-long social procedure which makes students more motivated to learn. LeNoue, Hall, and Eighmy (2011) state that through online environments, learners indeed establish and maintain communities of learning by participating in various behaviors and actions that are associated with offline communities.

In addition, according to Hrastinski and Dennen (2012), learning experiences are a blend of: 1-informal learning such as personal learning and online learning, 2-formal learning which is structured learning. Social networking sites are tools that allow experiences of informal learning in education. Moreover, according to Attwell (2007), informal learning, which depends on the learners willing to use social networking sites, can be used to boost classroom learning and formal learning. Selwyn (2007) states that evidence that shows that social networking sites support and assist informal learning in the community and at home is growing. Therefore, informal learning has become an essential factor in educational process for students of all levels and ages. Chayko (2008) conducted a study in the United States and the result showed that ninety-seven percent of the interviewees replied that they use social networking sites for practical and useful purposes. The participants of the study said that they used social networking sites for learning, academic and scientific inquiry, and gathering information. Moreover, Perlov and Guzansky (2014) conducted a study that illustrated that Saudi Arabia had the highest number of users in the whole world in terms of using YouTube and Twitter.

The Center for Community College Students' Engagement (2010) conducted a study in the University of Texas and the results illustrated that ninety-five percent of the students whose ages range between 18-24 use social networking sites. The findings also showed that students who used social networking sites for learning and educational reasons recorded a higher level of involvement than the students who refused to use social networking sites. Moreover, a study conducted by Kumar (2012) showed that the majority of Sikkim University students in India used social networking sites for learning and academic purposes in comparison to establishing friendships. Another study by Asiri and Alqarni (2015) carried out in Jeddah, Saudi Arabia investigated the advantages of using Twitter as a tool for learning English outside and inside the classroom. The results showed that Twitter had a positive impact on the process of learning English. Furthermore, Allam (2016) conducted a study In Saudi Arabia to investigate students' acceptance of Twitter as a tool for learning English. The results illustrated that students had positive acceptance of Twitter as a learning tool for learning English.

However, according to LeNoue et al. (2011), some students might be against the use of social networking sites and new technology. Students may not have much experience using them. Students may think they lack skill or access to the Internet. However, students who do not have the experience and skill to use the Internet have to gain proficiency in using new technologies because they are becoming constant and important fixtures and parts in our life.

\subsection{Gender Differences and Social Networks Sites}

There is a lot of attention on gender differences in learning. Gender differences have gained a lot of attention and focus because they play a vital role on the usage of the Internet and applications. There is a relationship between the use of the Internet and gender differences. Moreover, according to Spanier (2000), attitudes towards using the Internet is related to gender differences. Kayaoglu (2012) conducted a study in Turkey that revealed that there was a positive attitude towards the use of the Internet and technology among male participants while female participants had negative attitudes and they were not as confident as the male participants. In addition, according to Shashaani's study in Pittsburgh (1994), she stated that in comparison between male and female students, female students had negative attitudes and were less experienced in terms of utilizing computers and the Internet. Jackson, Ervin, Gardner, and Schmitt (2001) conducted a study in the United States and the results illustrated that males were more skillful, more confident, and had a positive perception and attitude toward using the 
Internet and its software than females. Nevertheless, according to Herring (2009), the results of his study in Italy showed that males did not post massages frequently. Additionally, males posted shorter massages in an online forum in comparison to females.

Gender differences are still an observable issue when it comes to the idea of using the Internet and its applications for learning purposes. We cannot deny the fact that gender plays an important role and can be considered one of the most essential factors that affect the use of the Internet for educational purposes as well as the choice of social networking sites. For example, males may like to use Twitter while females like to use Facebook. According to Wang, Wu, and Wang (2009), the results of their study in Taiwan illustrated that there were remarkable gender differences among users and the incorporation of learning through mobile phones. Moreover, Alsuraihi, Almaqati, Abughanim, and Jastaniah (2016) administered a study in Saudi Arabia to investigate gender differences in using social media for learning purposes. The results illustrated that both male and female students like to use YouTube. However, male students like to use Twitter and Wikis more than female students for learning purposes. Numerous studies have showed that when people have the intention to use social networking sites and its technologies, there are gender differences, which affects their intention and attitudes. According to Huang, Denice, and Sun (2013), they conducted a study in the United States on six social network sites and applications which were: online games, Wikis, blogs, immersive virtual environments, online video sharing, and social networking sites. The results illustrated that there were noticeable gender differences between male and female students. Females were more uneasy when using these social networking sites and applications in comparison to males who were more confident. Another study was carried out in Australia by Noguti, Singh, and Waller (2016) to explore students' gender differences and their motivation to apply Facebook to search information. The results illustrated that females like to use Facebook for learning new ideas and seeking information more than males. Due to the significance of social networking sites on gender roles and how they are influenced by them, this field needs to be examined more to help to understand gender differences in terms of using social networking sites for learning purposes. In addition, as it can be noticed that there has been increasing access and use of the Internet, especially with the younger generation who have been familiarized early on to the Internet and computers. The early exposure to the Internet and its services can lead to the decrease of gender differences (Mossberger, Tolbert, \& Stansbury, 2003).

\section{Methodology}

\subsection{Participants}

The participants of this study were 20 female and male foundation year students at the Englsih Language Institute (ELI), King Abdul Aziz University (KAU) in the city of Jeddah, Saudi Arabia. Foundation year students take four modules (Cambridge English Language Series) in one academic year. Ten female and ten male foundation year students were selected randomly. Both male and female students were enrolled in the level 104 course.

\subsection{Research Design}

The examination of this study was in the form of a case study. Due to this paper purpose, which was understanding students' perceptions and attitudes towards using social network sites for learning English, the researcher used a qualitative research method for deeper analysis of the data. Patton (2002) states that "qualitative methods facilitate study of issues in depth and detail. Approaching fieldwork without being constrained by predetermined categories of analysis contributes to the depth, openness, and detail of qualitative inquiry" (p. 14). Moreover, McCracken (1988) states that "Qualitative methods are most useful and powerful when they are used to discover how the respondent sees the world" (p. 21). The qualitative method was based on an open-ended questions questionnaire. The questionnaire had two parts. The first part of the questionnaire contained demographic characteristics while the second part had four questions to better understand students' perceptions and attitudes towards using social network sites, additionally to determine frequently used social networking sites by male and female students.

\subsection{Data Collection Procedures}

The data of this paper were collected through distributing open-ended questionnaires to students randomly. Since there is a colleague who works as an assistant professor at King Abdul-Aziz University in the Medical College, he assisted in collecting the data by asking a friend who works at the ELI in the male section to distribute the questionnaires among the male students. Data was collected from the female section by a female colleague to distribute the questionnaires among the female students. 


\subsection{Instrumentation}

The instrument of this study was an open-ended questionnaire. The questions were analyzed thematically. The questionnaire had two parts. The first part contained demographic characteristics while the second part had four questions to better understand students' perceptions and attitudes towards using social networking sites, additionally to determine frequently used social networking sites by male and female students.

\section{Results}

\subsection{Perceptions and Attitudes Towards Using Social Networking Sites for Learning English}

For the first research question, which was:

'what are students' perceptions and attitudes towards using social network sites for learning English?'

The results are presented in Table 1 below.

Table 1. Students' perceptions and attitudes toward using social networking sites for learning English

\begin{tabular}{llll}
\hline Gender & Number & Positive attitude & Negative attitude \\
\hline Male & 10 & 10 & 0 \\
Female & 10 & 2 & 8 \\
\hline
\end{tabular}

The results illustrated that the ten male students had a positive attitude toward using social network sites for learning English. One of them stated that "Yes, the best starting point for a real practising of the language" while other male student stated that "I like to use them because they let me practice the language with native speakers".

On the other hand, only two female students had a positive attitude towards using social networking sites for learning English while eight female students had negative attitudes. Most of the female students stated that "No, social network sites information and sources are not reliable." The other female students stated that "I do not like learning English from social network sites because they do not improve the language".

\subsection{The Difference between Male and Female Students in Terms of Learning English Through}

Social Network Sites Inside and Outside the Classroom:

Regarding the second question:

'Is there a difference between female and male foundation year students in terms of learning English through social network sites inside and outside the classroom?'

The results are indicated in Table 2 below.

Table 2. Difference between female and male students in terms of learning English through social network sites inside and outside the classroom

\begin{tabular}{|c|c|c|c|c|c|}
\hline Gender & Number & $\begin{array}{lr}\text { With } & \text { using } \\
\text { social } & \text { network } \\
\text { sites } & \text { inside } \\
\text { classrooms }\end{array}$ & $\begin{array}{lr}\text { Against } & \text { social } \\
\text { network } & \text { sites } \\
\text { inside } & \\
\text { classrooms } & \end{array}$ & $\begin{array}{lr}\text { With } & \text { using } \\
\text { social } & \text { network } \\
\text { sites } & \text { outside } \\
\text { classrooms }\end{array}$ & $\begin{array}{lr}\text { Against } & \text { social } \\
\text { network } & \text { sites } \\
\text { outside } & \\
\text { classrooms } & \end{array}$ \\
\hline Male & 10 & 10 & 0 & 10 & 0 \\
\hline Female & 10 & 2 & 8 & 2 & 8 \\
\hline
\end{tabular}

The results illustrated that the ten male students preferred and liked the idea of using social networking sites inside and outside of class. Some of the male students had positive reactions and one stated that "Very good, because when practicing inside and outside classrooms, I will improve my language very fast" while the other male student stated that "I like it because it is like using and practicing the language all the time not just inside classrooms".

However, concerning the female students, only two female students liked and preferred the notion of using social networking sites inside and outside classrooms while eight female students were totally against using them inside 
and outside classrooms. The majority of the female students perceived an opposite reaction and one stated that " $I$ do not like to use social network sites inside and outside classrooms, the teacher has to be presented in order to correct my mistakes because she knows what is right and what is wrong unlike social networking sites".

4.3 Social Networking Sites that areFfrequently Used by Female and Male Foundation Year Students in Order to Learn English

Concerning the third research question, which was:

'What are the social network sites that are frequently used by males and females in order to learn English?':

The results are indicated in Table 3 below.

Table 3. Social networking sites that are frequently used by female and male foundation year students in order to learn English

\begin{tabular}{lllll}
\hline Gender & Number & YouTube & Twitter & None \\
\hline Male & 10 & 7 & 3 & 0 \\
Female & 10 & 2 & 0 & 8 \\
\hline
\end{tabular}

The results showed that seven male students used YouTube frequently to learn English, and three male students used Twitter frequently for the purpose of learning English. One of the male students stated that "I like to use YouTube because I can find a lot of videos that help me to learn how to use the language in everyday life situations." Another male student stated that "I prefer to use Twitter because it improves my writing".

However, according to the results, only two female students used YouTube frequently to learn English while eight female students did not use any social networking site for learning English. Most of the female students perceived in a negative way. One stated that "I do not trust the information of any Social network site so I do not use any one".

\section{Discussion and Conclusion}

For the first research question: What are the students' perceptions and attitudes towards using social networking sites for learning English?

The results illustrated that male students had positive perceptions and attitudes towards using social networking sites more than female students who had generally negative attitudes. It can be said that this result is in line with the findings of numerous related studies such as Kayaoglu, 2012; and Shashaani 1994. These studies showed that male students had positive attitudes towards using the Internet and its applications while female students had negative attitudes because they were less experienced and less confident compared to the male students.

Regarding the second research question: Is there a difference between male and female foundation year students in terms of learning English through social network sites inside and outside the classroom?

The results illustrated that male students preferred the idea of using social networking sites inside and outside the classroom more than female students who were against the idea of using social networking sites inside and outside the classroom. This finding is not comparable to the findings of the study that was conducted by Kumar (2012) which revealed that the larger number of Sikkim University students mostly used social networking sites for learning and educational purposes, compared to establishing friendships.

For the third research question: What are the social network sites that are frequently used by female and male foundation year students in order to learn English?

The results showed that YouTube was the most frequently applied social networking site for learning English by male students while most female students did not have any favorite social networking sites because they did not use them for learning English. This result is consistent with the result of a study that was conducted by Perlov and Guzansky (2014), which showed that the number of YouTube users in the Kingdom of Saudi Arabia is the highest in the world.

To conclude, the main aim of this study was to understand students' perceptions and attitudes toward using social networking sites for learning English as well as to determine if there is a difference between male and female foundation year students in terms of learning English through thses sites. Additionally, the study aimed to identify the frequently used social networking sites that are used by male and female students to learn English. 


\section{Limitation of the Study}

The research was administered at King Abdu Aziz University. Thus, the results cannot be generalized to other colleges and universities. Additionally, the research is limited to King Abdul Aziz University female and male foundation year students.

\section{Suggestions for Further Research}

Two suggestions are recommended for future research. The first one is to take into account other groups in the educational process such as administrators and faculty to examine whether there are differences between faculty, students, and administrators in their perceptions and attitudes of using social networking sites for learning English. The second one is to administer a comparative research to discover whether there are differences between students' perceptions and attitudes towards using these sites for learning English at King Abdul-Aziz University and the perceptions and attitudes of students at other Saudi universities.

\section{Acknowledgement}

We would like to sincerely thank Dr. Ehab Alshoaibi for his continuous support.

\section{References}

Ajzen, I., \& Fishbein, M. (1980). Understanding attitudes and predicting social behavior. Englewood Cliffs, NJ: Prentice-Hal.

Allam, M. (2016). The use of Twiiter as a learning tool for preparatory year EFL Saudi students: An empirical study (Unpiblished Master's thesis). University of King Abdulaziz, Jeddah, Saudi Arabia.

Alsuraihi, A., Almaqati, A., Abughanim, S., \& Jastaniah, N. (2016). Use of social media in education among medical students in Saudi Arabia. Korean Journal of Medical Education, 28(4), 343-354. https://doi.org/10.3946/kjme.2016.40

Attwell, G. (2007). The personal learning environments: The future of eLearning? E Learning Papers, 2(1), 1-8.

Boyd, D. M., \& Ellison, N. B. (2007). Social network sites: Definition, history, and scholarship. Journal of Computer-Mediated Communication, 13(1), 210-230. https://doi.org/10.1111/j.1083-6101.2007.00393.x

Brady, K. P., Holcomb, L. B., \& Smith, B. V. (2010). The use of alternative social networking sites in higher educational settings: A case study of the e-Learning benefits of Ning in education. Journal of Interactive Online Learning, 9(2), 151-170.

Center for Community College Student Engagement. (2010). The Heart of Student Success: Teaching, Learning, and College Completion (2010 CCCSE Findings). Austin, TX: The University of Texas at Austin, Community College Leadership Program.

Chayko, M. (2008). Portable communities: The social dynamics of online and mobile connectedness. Albany, NY: State University of New York Press.

Espuny, C., Gonzalez, J., Lleixà, M., \& Gisbert, M. (2011). University students' attitudes towards and expectations of the educational use of social networks. RUSC. Universities and Knowledge Society Journal, 8(1), 186-199. https://doi.org/10.7238/rusc.v8i1.839

Glover, J. A., \& Bruning, R. H. (1990). Educational psychology: Principles and applications (3rd ed.). Virginia: Scott, Foresman Little Brown Higher. https://doi.org/10.1037/0022-0663.82.2.291

Godwin-Jones, R. (2006). Tag clouds in the blogosphere: Electronic literacy and social networking. Language Learning \& Technology, 10(2), 8-15.

Harrison, R., \& Thomas, M. (2009). Identity in online communities: Social networking sites and language learning. International Journal of Emerging Technologies and Society, 7(2), 109-124.

Herring, S. C. (2009). Symbolic capital in a virtual heterosexual market: Abbreviation and insertion in Italian iTV SMS. Written Communication, 26(5), 5-31. https://doi.org/10.1177/0741088308327911

Hrastinski, S., \& Dennen, V. (2012). Personal learning environments, social media, and self-regulated learning: A natural formula for connecting formal and informal learning. The Internet and Higher Education, 15(1), 3-8. https://doi.org/10.1016/j.iheduc.2011.06.002

Huang, W. H. D., Denice, W. H., \& Sun, J. Y. (2013). Gender divide and acceptance of collaborative Web 2.0 applications for learning in higher education. Internet and Higher Education, 16, 57-65. https://doi.org/10.1016/j.iheduc.2012.02.001 
Jackson, I. A., Ervin, K. S., Gardner, P. D., \& Schmitt, N. (2001). Gender and the internet: Women communicating and men searching. Sex Roles, 44, 363-379. https://doi.org/10.1023/A:1010937901821

Kayaoglu, N. M. (2012). Gender-Based differences in language learning strategies of science students. Journal of Turkish Science Education, 9(2), 50-70.

Kumar, N. (2012). User perception and use of social networking sites by Sikkim University students, $8^{\text {th }}$ Convention PLANNER- 2012, Sikkim University.

LeNoue, M., Hall, T., \& Eighmy, M. (2011). Adult education and the social media revolution. Adult Learning, 22, 4-12. https://doi.org/10.1177/104515951102200201

Lomick, L., Lord, M., \& Manzer, M. (2003). Merging foreign language theory and practice in designing technology-based tasks. $\quad$ Retrieved on January from http://grove.ufl.edu/ cittdev/Lord/pdfs/ABCsOfTaskDesign.pdf

McCracken, G. (1988). The long interview. Newbury Park, CA: Sage Publications. https://doi.org/10.4135/9781412986229

Mossberger, K., Tolbert, C., \& Stansbury, M. (2003). Virtual inequality. Washington, DC: Georgetown University Press.

Noguti, V., Singh, S., \& Waller, D. S. (2016). Gender Differences in Motivations to Use Social Networking Sites. In R. English, \& R. Johns (Eds.), Gender Considerations in Online Consumption Behavior and Internet Use (pp. 32-49). Hershey, PA: IGI Global. https://doi.org/10.4018/978-1-5225-0010-0.ch003

Patton, M. Q. (2002). Qualitative research and evaluation methods. Sage Publications.

Perlov, O., \& Guzansky, Y. (2014). The social discourse in Saudi Arabia: The conservative and radical camps are the dominant voices. INSS Insight, 511.

Selwyn, N. (2007). Web 2.0 applications as alternative environments for informal learning. OECD CERIKERIS International expert meeting on ICT and educational performance, Organization for Economic Co-Operation and Development, Cheju Island, South Korea.

Seo, K. (2013). Using social media effectively in the classroom. Blogs, Wikis, Twitter, and More. International Journal of Emerging Technologies and Society, 7(2), 109-124.

Shashaani, L. (1994). Gender differences in computer experience and its influence on computer attitudes. Journal of Educational Computing Research, 11, 347-367. https://doi.org/10.2190/64MD-HTKW-PDXV-RD62

Silius, K., Miilumäki, T., Huhtamäki, J., Tebest, T., Meriläinen, J., \& Pohjolaine, S. (2010). Students' motivations for social media enhanced studying and learning. Knowledge Management \& ELearning: An International Journal, 2(1), 70-80

Spanier, G. (2000). Five challenges facing American higher education. Executive Speeches, 14(6), 19-25.

Wang, Y. S., Wu, M. C., \& Wang, H. Y. (2009). Investigating the determinants and age and gender differences in the acceptance of mobile learning. British Journal of Educational Technology, 40, 92-118. https://doi.org/10.1111/j.1467-8535.2007.00809.x

\section{Appendix A}

Questionnaire to know students' perceptions and attitudes toward using social network sites for learning English

First- Demographic information:

1 -Age.......

2-Gender.

3-Level in university.

4-Do you have a computer at home.........

5 -Do you have a mobile phone.

Second- Please answer the following questions with mentioning the reasons:

1-Do you like to learn English through social network sites or not? Explain why? 
2-Do you like the idea of using social networking sites for learning English inside and outside of the classroom? Explain why?

3-Do you use social network sites to help you with your academic homework? Explain why?

4-What is the most used social network site for you to learn English? Explain why?

\section{Copyrights}

Copyright for this article is retained by the author(s), with first publication rights granted to the journal.

This is an open-access article distributed under the terms and conditions of the Creative Commons Attribution license (http://creativecommons.org/licenses/by/4.0/). 